\title{
PENGARUH METODE INQUIRY TERHADAP PENINGKATAN PEMAHAMAN KONSEP MATEMATIKA
}

\author{
Ihwan Zulkarnain \\ Program Studi Pendidikan Matematika, Universitas Indraprasta PGRI Jakarta \\ Email: Irvan_arie@yahoo.com
}

\begin{abstract}
Abstrak:
Tujuan Penelitian adalah untuk membuktikan secara empiris adanya pengaruh metode inquiry terhadap peningkatan pemahaman konsep matematika siswa. Metode penelitian yang dilakukan merupakan metode eksperimen dengan membandingkan siswa di kelas IX-A yang melakukan pembelajaran melalui metode inquiry sebagai kelas eksperimen dan siswa di kelas IX-B yang melakukan pembelajaran melalui metode ekspositorisebagai kelas kontrol.Penelitian dilaksanakan di SMP Karya Pakuan Kabupaten Bogor tahun pelajaran 2018/2019.Pengambilan sampel dilakukan dengan teknik purposive sampling. Sampel penelitian ini adalah 60 orang siswa dengan latar belakang kurikulum yang sama tanpa cluster khusus atau kemampuan perkelas yang sama rata. Instrumen penelitian menggunakan tes evaluasi pemahaman konsep berupa test essay. Teknik analisis data menggunakan uji-t. Berdasarkan perhitungan didapat $t_{\text {hitung }}=9,39$ dan $t_{\text {tabel }}=2,001$ dengan taraf signifikansi $5 \%$ yang berarti nilai $t_{\text {hitung }}>t_{\text {tabel }}$. Hasil tersebut menunjukkan bahwa $\mathrm{H}_{0}$ ditolak dan $\mathrm{H}_{1}$ diterima. Diterimanya $\mathrm{H}_{1}$, hal ini berarti telah membuktikan kebenaran dari hipotesis yang menyatakan bahwa pemberian metode inquiry berpengaruh terhadap pemahaman konsep matematika siswa.
\end{abstract}

Kata Kunci:Metode Inquiry, Metode Ekspositori dan Pemahaman Konsep Matematika.

\section{Pendahuluan}

Pendidikan merupakan proses dengan metode tertentu untuk memperoleh pengetahuan, pemahaman dan cara bertingkah laku yang sesuai dengan kehidupan di masyarakat. Dengan mengikuti pendidikan, manusia diharapkan mampu menghasilkan output yang berkualitas. Dari berbagai macam karakteristik input yang masuk dalam pendidikan, siswa diharapkan mampu menghasilkan output yang baik dan memiliki fungsi di dalam kehidupannya kelak. Demikian itu merupakan tugas dari pendidikan yang tidak bisa diabaikan (Akbar, 2013).

Sasaran utama dari pendidikan adalah membina para peserta didik sampai menyelesaikan studinya sedemikian rupa sehingga mereka menjadi manusia yang memiliki pengetahuan, sikap, dan keterampilan yang baik.Begitu pula dalam pembelajaran di sekolah khususnya matematika. Pendidikan sering terjadi di bawah bimbingan orang lain, tetapi juga memungkinkan secara otodidak. Setiap pengalaman yang memiliki efek formatif pada cara orang berpikir, merasa, atau tindakan dapat dianggap pendidikan. Pendidikan umumnya dibagi menjadi tahap seperti prasekolah, sekolah dasar, sekolah menengah hingga perguruan tinggi (Bartolomeus, 2013).

Proses pembelajaran merupakan dua proses yang saling berkaitan.Belajar adalah suatu aktifitas mental (psikis) yang berlangsung dalam interaksi dengan lingkungannya yang menghasilkan perubahan yang bersifat relatif konstan, (Siregar, 2010: 5).Salah satu rangkaian kegiatan interaksi pembelajaran adalah interaksi antara pendidik dengan peserta didik dan komunikasi timbal balik yang berlangsung dalam situasi edukatif untuk mencapai tujuan belajar. Interaksi dan komunikasi timbal balik antara guru dan peserta didik merupakan ciri dan syarat utama bagi berlangsungnya proses belajar mengajar. Interaksi tersebut merupakan interaksi edukatif yang tidak hanya menyampaikan materi pelajaran melainkan juga mengajarkan keterampilan dan menanamkan nilai-nilai pada diri peserta didik yang mengikuti kegiatan pembelajaran. 
Dalam kegiatan belajar mengajar, pendidik biasanya menggunakan beberapa metode. Metode yang digunakan dalam proses belajar mengajar pada dasarnya menekankan pada proses pembelajaran yang bertujuan untuk memperoleh suatu konsep. Selain itu, metode pembelajaran yang digunakan diharapkan dapat membantu peserta didik dengan cara membangkitkan motivasi belajarnya, meningkatkan keaktifan dan kreatifitas, membantu peserta didik dalam memahami konsep serta mengaplikasikannya dalam kehidupan sehari-hari.

Salah satu faktor penyebab kurangnya penguasaan materi matematika bagi peserta didik diantaranya adalah masih banyak guru yang menerapkan pembelajaran konvensional, dalam prosesnya guru menerangkan materi dengan metode ceramah, peserta didik duduk manis mendengarkan dan mencatat konsep-konsep abstrak yang disampaikan oleh guru tanpa bisa mengkritisi apa arti kosep itu, lalu konsep itu biasanya sudah dalam bentuk persamaan matematika yang diterapkan pada kasus-kasus khusus. Saat latihan mereka biasa mengerjakan soal-soal yang setipe dengan yang dicontohkan oleh gurunya namun pada saat ada soal yang membutuhkan pemahaman konsep mereka mengalami kesulitan untuk menyelesaikannya.

Dalam Pembelajaran seperti itu, siswa kurang dapat mengembangkan kreatifitas, kemampuan berpikir kritis peserta didik pada pelajaran matematika. Seperti yang dikatakan Lestari (Leonard, 2015) bahwa Matematika adalah ilmu pengetahuan tentang logika mengenai bentuk, susunan, besaran, dan konsepkonsep yang terbagi menjadi beberapa cabang yang dalam setiap kajiannya bersifat logis, sistematis, dan konsisten. Keadaan yang demikian membuat peserta didik tidak mendapatkan rangsangan dalam melakukan penemuan konsep-konsep atau rumusan matematika. Peserta didik tidak dibiarkan secara mandiri dalam penemuan konsep tersebut. Peran serta guru dalam kegiatan pembelajaran seperti itu tidaklah efektif.

Kegiatan pembelajaran yang efektif adalah pembelajaran yang terpusat kepada peserta didik. Peserta didik diberikan kesempatan untuk menemukan konsep matematika yang ada dengan bantuan dan arahan dari guru. Pada pembelajaran seperti ini, peserta didik akan dituntut untuk berpikir secara kritis, dituntut dalam memberikan ide-ide atau gagasan dalam penemuan dan penyelesaian suatu masalah. Hal ini dapat meningkatkan kemandirian peserta didik dalam menyelesaikan permasalahan matematika. Konsep pembelajaran yang mengedepankan siswa dalam menemukan suatu penyelesaian salah satunya adalah pembelajaran dengan menggunakan metode pembelajaran inquiry.

Kata Inquiry dalam bahasa inggris berarti pertanyaan, atau pemeriksaan, penyelidikan. Dapat diartikan bahwa Inquiry sebagai proses bertanya dan mencari tahu jawaban terhadap pertanyaan ilmiah yang diajukannya. Sanjaya (2008) berpendapat bahwa "Pembelajaran Inquiry adalah rangkaian kegiatan pembelajaran yang menekankan pada proses berpikir secara kritis dan analitis untuk mencari dan menemukan sendiri jawaban dari suatu masalah yang dipertanyakan".

Zulfiani (2009) menjelaskan dalam proses belajar mengajar, Inquiry ini digunakan sebagai metode pengajaran yang memungkinkan ide siswa berperan dalam suatu penyelidikan (investigasi) yang akan dilakukan oleh pembelajar/siswa. Salah satu prinsip utama inquiry, yaitu siswa dapat mengkonstruks sendiri pemahamannya dengan melakukan aktivitas aktif dalam pembelajarannya.Sagala menyatakan Metode inkuiri merupakan metode pembelajaran yang berupaya menanamkan dasar-dasar berfikir ilmiah pada diri siswa yang berperan sebagai subjek belajar, sehingga dalam proses pembelajaran ini siswa lebih banyak belajar sendiri, mengembangkan kreativitas dalam memecahkan masalah.

Dalam pembelajaran Inquiry siswa harus menemukan sendiri konsep materi yang sedang dipelajari.Seorang siswa bertindak sebagai ilmuan (scientist), ditandai dengan mengajukan pertanyaan, merumuskan masalah, berhipotesis, melakukan eksperimen, menerapkan 
konsep dan memiliki sikap ilmiah. Pembelajaran Inquiry menekankan pada proses berpikir secara kritis dan analitis untuk mencari dan menemukan masalah yang dipertanyakan.

Sedangkan penggunaan metode ekpositori (kelas kontrol) bertolak belakang dari pandangan bahwa tingkah laku siswa dan penyebaran pengetahuan dikontrol dan ditentukan oleh guru atau pengajar. Metode ekspositorimemiliki kesamaan dengan metode ceramah, karena sifatnya memberikan informasi. Beda ekspositori dengan ceramah adalah dominasi guru yang dikurangi. Dalam metode ekspositori guru memberikan informasi hanya pada waktuwaktu tertentu yang diperlukan siswa, misalnya pada awal pengajaran, atau untuk suatu topik yang baru.

Menurut Makmun (Suyanti, 2010) mengemukakan bahwa guru menyajikan bahan dalam bentuk yang telah disiapkan secara rapi, sistematik, dan lengkap sehingga siswa tinggal menyimak dan mencernanya secara teratur dan tertib. Sedangkan pembelajaran ekpositori Menurut Suyanti (2010) adalah metode yang digunakan guru dalam mengajar keseluruhan konsep, fakta dan aturan-aturan matematika kepada siswa, sedangkan siswa mendengarkan dan bertanya apabila tidak mengerti yang telah diterangkan oleh guru.

Pembelajaran ekspositori merupakan suatu pembelajaran dimana bahan pelajaran yang disajikan telah disusun secara final (sampai bentuk akhir) dan siswa belajar dengan menerima bahan yang telah disusun tersebut.Peran guru dalam metode ini lebih mendominasi kegiatan, yaitu guru mengontrol alur pelajaran dengan menyampaikan informasi dan mendemonstrasikan penyelesaian suatu soal.Dalam hal ini Liberna dan Wiratomo memiliki pendapat yang sama yaitu bahwa "metode ekspositori merupakan cara untuk menyampaikan ide atau memberikan informasi dengan berbicara atau tertulis" (Liberna dan Wiratomo, 2013).

Dari beberapa uraian yang telah dijelaskan maka dapat disimpulkan bahwa metode ekspositori adalah metode yang penyampaian materinya secara verbal dari seorang guru karena metode ini menempatkan guru sebagai pusat pembelajaran, dengan menyajikan bahan yang telah disiapkan dengan rapi, sistematik dan lengkap agar siswa dapat menyimak dan mencernanya secara teratur dan tertib. Tujuan penelitian ini adalah untuk mengidentifikasi pengaruhnya metode inquiry terhadap peningkatan pemahaman konsep yang dimiliki oleh siswa kelas IX SMP Karya Pakuan Kabupaten Bogor pada materi bangun ruang sisi lengkung.

\section{MetodePenelitian}

Jenis penelitian yang diambil oleh peneliti adalah eksperimen.Metodeyang digunakandalampenelitianiniadalahmetode

Quasi

Experimental

Design.Desainpenelitianyang

dipergunakandalam

penelitianini

adalahdesain

Pretest-Posttest

Nonequivalent-Group Design. Menurut Sugiyono (2013), desain ini hampir sama dengan Pretest-Posttest Equivalent-Group perbedaannya pada penempatan group tidak dapat dilakukan dengan random. Senada dengan hal tersebut, Suryabrata (2011) mengatakan untuk menyelidiki kemungkinan saling hubungan sebab akibat dengan cara mengenakan perlakuan dan membandingkan hasil dari eksperimen dengan kontrol. Pada penelitian ini kelas eksperimen di ukur pemahamannya sebelum (pretest) dan setelah melakukan kegiatan pembelajaran (posttest) berbasis inquiry.Instrumen yang digunakan pada penelitian ini adalah tes hasil belajar dalam bentuk uraian pada materi bangun ruang sisi lengkung.yang berjumlah 11 dari 15 soal valid yang direncanakan untuk mengukur tingkat pemahaman konsep matematika siswa.

Data dianalisis terlebih dahulu dengan uji persyaratan, yaitu uji normalitas, homogenitas dan pengujian hipotesis.Populasi pada penelitian ini adalah seluruh siswa reguler kelas IX yang berjumlah 211 dan terdaftar mengikuti mata pelajaran Matematika pada semester ganjil 2018/2019 di SMP Karya Pakuan Kabupaten Bogor.Sedangkan sampel yang diambil pada penelitian terbagi menjadi dua yaitu kelas eksperimen dan kelas kontrol. 
Yang bertindak sebagai kelas eksperimen adalah kelas IX-A dan kelas kontrol adalah kelas IX-B dengan jumlah sampel yang diambil adalah sama yaitu 30 siswa.

Teknik pengambilan sampel dilakukan dengan carapurposive sampling karena pengambilan anggota sampel dari populasi dilakukan dengan tujuan dan pertimbangan-pertimbangan tertentu seperti, seperti kondisi kelas, jumlah siswa dalam kelas, homogenitas kelas dan lain sebagainya. Teknik atau metode pengumpulan data pada penelitian ini adalah menggunakan tes.

\section{HasildanPembahasan}

Hasil

Data Pemahaman Konsep Matematika Kelas Eksperimen

Data nilaipretest dan posttest siswa pada pokok bahasan bangun ruang sisi lengkung dengan menggunakan metode pembelajaran inquirydi kelas eksperimen adalah sebagai berikut:

Tabel 1. Distribusi Hasil Pretest Kelas Eksperimen

\begin{tabular}{ccccccc}
\hline No. & Interval & $\begin{array}{c}\text { Frekuensi } \\
\left(f_{\mathrm{i}}\right)\end{array}$ & $\begin{array}{c}\text { Titik Tengah } \\
\left(X_{\mathrm{i}}\right)\end{array}$ & \multicolumn{1}{c}{$X_{\mathrm{i}}^{2}$} & $f_{\mathrm{i} .} X_{\mathrm{i}}$ & \multicolumn{1}{c}{$f_{\mathrm{i} .} X_{\mathrm{i}}^{2}$} \\
\hline 1. & $39-44$ & 4 & 41,5 & 1722,25 & 166 & \multicolumn{1}{c}{6889} \\
2. & $45-50$ & 9 & 47,5 & 2256,25 & 427,5 & 20306,25 \\
3. & $51-56$ & 10 & 53,5 & 2862,25 & 535 & 28622,5 \\
4. & $57-62$ & 3 & 59,5 & 3540,25 & 178,5 & 10620,75 \\
5. & $63-68$ & 1 & 65,5 & 4290,25 & 65,5 & 4290,25 \\
6. & $69-74$ & 3 & 71,5 & 5112,25 & 214,5 & 15336,75 \\
\hline & Jumlah & 30 & & 19783,5 & 1587 & 86065,5 \\
\hline
\end{tabular}

Tabel 2. Tabel Distribusi Hasil Posttest Kelas Eksperimen

\begin{tabular}{ccccccc}
\hline No. & Interval & $\begin{array}{c}\text { Frekuensi } \\
\left(f_{\mathrm{i}}\right)\end{array}$ & $\begin{array}{c}\text { Titik Tengah } \\
\left(X_{\mathrm{i}}\right)\end{array}$ & $X_{\mathrm{i}}^{2}$ & $f_{\mathrm{i} . X_{\mathrm{i}}}$ & $f_{\mathrm{i} . X_{\mathrm{i}}^{2}}$ \\
\hline 1. & $48-54$ & 2 & 51 & 2601 & 102 & 5202 \\
2. & $55-61$ & 8 & 58 & 3364 & 464 & 26912 \\
3. & $62-68$ & 7 & 65 & 4225 & 455 & 29575 \\
4. & $69-75$ & 4 & 72 & 5184 & 288 & 20736 \\
5. & $76-82$ & 3 & 79 & 6241 & 237 & 18723 \\
6. & $83-89$ & 6 & 86 & 7396 & 516 & 444376 \\
\hline & Jumlah & 30 & & 29011 & 2062 & 145524 \\
\hline
\end{tabular}

Tabel 3. Perbandingan Pemahaman Konsep Matematika Kelas Eksperimen

\begin{tabular}{ccc}
\hline Statistik & Nilai Pretest & Nilai Posttest \\
\hline Nilai Terendah & 39 & 48 \\
Nilai Tertinggi & 71 & 88 \\
Mean & 52,90 & 68,73 \\
Median & 51,70 & 66,50 \\
Modus & 51,25 & 60,50 \\
Varians & 72,86 & 130,89 \\
Simpangan Baku & 8,53 & 11,44 \\
\hline
\end{tabular}

Berdasarkan tabel perbandingan nilai pretest dan posttest kelas eksperimen tersebut terlihat dari hasil rata-rata mengalami kenaikan sebesar 29,92\%. Sehingga, dapat disimpulkan bahwa terdapat peningkatan pemahaman konsep matematika siswa dari sebelum diberikan pembelajaran dengan metode inquiry dan setelah diberikan pembelajaran dengan metode inquiry. 


\section{Deskripsi Data Pemahaman Konsep Matematika Kelas Kontrol}

Seperti halnya pada kelas eksperimen, peneliti pun mengumpulkan data pretest dan posttest untuk mengetahui sejauh mana pemahaman konsep siswa mengenai materi bangun ruang sisi lengkung yang diberi pembelajaran dengan metode ekspositori di kelas kontrol adalah sebagai

berikut:

Tabel 4. Tabel Distribusi Frekuensi Hasil Pretest Kelas Kontrol

\begin{tabular}{ccccccc}
\hline No. & Interval & $\begin{array}{c}\text { Frekuensi } \\
\left(f_{\mathrm{i}}\right)\end{array}$ & $\begin{array}{c}\text { Titik Tengah } \\
\left(X_{\mathrm{i}}\right)\end{array}$ & $X_{\mathrm{i}}^{2}$ & $f_{\mathrm{i}} . X_{\mathrm{i}}$ & $f_{\mathrm{i}} X_{\mathrm{i}}^{2}$ \\
\hline 1. & $41-45$ & 6 & 43 & 1849 & 258 & 11094 \\
2. & $46-50$ & 8 & 48 & 2304 & 384 & 18432 \\
3. & $51-55$ & 7 & 53 & 2809 & 371 & 19663 \\
4. & $56-60$ & 4 & 58 & 3364 & 232 & 13456 \\
5. & $61-65$ & 3 & 63 & 3969 & 189 & 11907 \\
6. & $66-70$ & 2 & 68 & 4624 & 136 & 9348 \\
\hline & Jumlah & 30 & & 8919 & 1570 & 83800 \\
\hline
\end{tabular}

Tabel 5. Tabel Distribusi Frekuensi Hasil Posttest Kelas Kontrol

\begin{tabular}{cccccrc}
\hline No. & Interval & $\begin{array}{c}\text { Frekuensi } \\
\left(f_{\mathrm{i}}\right)\end{array}$ & $\begin{array}{c}\text { Titik Tengah } \\
\left(X_{\mathrm{i}}\right)\end{array}$ & $X_{\mathrm{i}}^{2}$ & $f_{\mathrm{i}} . X_{\mathrm{i}}$ & $f_{\mathrm{i}} X_{\mathrm{i}}^{2}$ \\
\hline 1. & $38-45$ & 4 & 41,5 & 1722,25 & 166 & 6889 \\
2. & $46-53$ & 6 & 49,5 & 2450,25 & 297 & 14701,5 \\
3. & $54-61$ & 14 & 57,5 & 3306,25 & 805 & 46287,5 \\
4. & $62-69$ & 3 & 65,5 & 4290,25 & 196 & 12870,5 \\
5. & $70-77$ & 1 & 73,5 & 5402,25 & 73,5 & 5402,25 \\
6. & $78-85$ & 2 & 81,5 & 6642,25 & 163 & 13284,5 \\
\hline & Jumlah & 30 & & 23813,5 & 1701 & 99435,5 \\
\hline
\end{tabular}

Tabel 6. Perbandingan Pemahaman Konsep Matematika Kelas Kontrol

\begin{tabular}{ccc}
\hline Statistik & Nilai Pretest & Nilai Posttest \\
\hline Nilai Terendah & 41 & 38 \\
Nilai Tertinggi & 66 & 82 \\
Mean & 52,33 & 56,70 \\
Median & 51,20 & 56,35 \\
Modus & 48,83 & 56,86 \\
Varians & 56,43 & 103,06 \\
Simpangan Baku & 7,51 & 10,15 \\
\hline
\end{tabular}

Berdasarkan tabel perbandingan nilai pretest dan postest kelas kontrol tersebut terlihat dari hasil rata-rata mengalami kenaikan sebesar $8,35 \%$. Sehingga, dapat disimpulkan bahwa terdapat peningkatan pemahaman konsep matematika siswa dari sebelum diberikan pembelajaran dengan metode ekspositori dan setelah diberikan pembelajaran dengan metode ekspositori.

\section{Pengujian Prasyarat Analisis}

Analisis yang digunakan dalam penelitian ini adalah uji hipotesis dengan uji-t dengan cara membandingkan nilai pretest dan postest kelas eksperimen dan kelas kontrol. Sebelum disajikan uji-t terlebih dahulu dipenuhi asumsi-asumsi atau persyaratan untuk analisis tersebut.Persyaratan analisis yang dimaksud adalah normalitas dan homogenitas. 
Uji Normalitas Nilai Pretest dan posttest Uji normalitas yang digunakan dalam penelitian ini adalah uji Chi-square.Uji normalitas dilakukan untuk mengetahui apakah data sampel berasal dari populasi berdistribusi normal atau tidak. Kriteria pengujiannya yaitu $\mathrm{x}^{2}$ hitung $\leq \mathrm{x}_{\text {tabel }}^{2}$

Tabel 7. Rekapitulasi Hasil Perhitungan Uji Normalitas Nilai Pretest

\begin{tabular}{ccccc}
\hline Kelompok & $\begin{array}{c}\text { Jumlah } \\
\text { Sampel }\end{array}$ & $\mathrm{x}^{2}{ }_{\text {hitung }}$ & $\mathrm{x}^{2}{ }_{\text {tabel }}$ & Keterangan \\
\hline $\begin{array}{c}\text { Eksperimen } \\
\text { Kontrol }\end{array}$ & 30 & 9,562 & 11,07 & $\begin{array}{c}\text { Kedua sampel berasal } \\
\text { dari populasi yang } \\
\text { berdistribusi normal }\end{array}$ \\
\hline
\end{tabular}

Tabel 8. Rekapitulasi Hasil Perhitungan Uji Normalitas Nilai Postest

\begin{tabular}{|c|c|c|c|c|}
\hline Kelompok & $\begin{array}{l}\text { Jumlah } \\
\text { Sampel } \\
\end{array}$ & $\mathrm{X}_{\text {hitung }}^{2}$ & $\mathrm{x}_{\text {tabel }}^{2}$ & Keterangan \\
\hline Eksperimen & 30 & 9,751 & 11,07 & rasal \\
\hline Kontrol & 30 & 9,678 & 11,07 & $\begin{array}{l}\text { dar1 populasi yang } \\
\text { berdistribusi normal }\end{array}$ \\
\hline
\end{tabular}

\section{Uji Homogenitas Nilai Pretest dan} posttest

Uji homogenitas digunakan untuk mengetahui apakah kedua kelas sampel berasal dari populasi yang homogen atau tidak.Uji homogenitas yang digunakan dalam penelitian ini adalah Uji Fisher, dengan kriteria pengujiannya $F_{\text {hitung }} \leq \mathrm{F}_{\text {tabel }}$.

Tabel 9. Rekapitulasi Hasil Perhitungan Uji Homogenitas Nilai Pretest

\begin{tabular}{ccccc}
\hline Kelompok & $\begin{array}{c}\text { Varians } \\
\left(\mathrm{S}^{2}\right)\end{array}$ & $\mathrm{F}_{\text {hitung }}$ & $\mathrm{F}_{\text {tabel }}$ & Kesimpulan \\
\hline Eksperimen & 64,96 & 1,153 & 1,882 & Kedua varians \\
Kontrol & 56,34 & 1,153 & 1,882 & populasi homogen \\
\hline
\end{tabular}

Tabel 10. Rekapitulasi Hasil Perhitungan Uji Homogenitas Nilai Postest

\begin{tabular}{ccccc}
\hline Kelompok & $\begin{array}{c}\text { Varians } \\
\left(\mathrm{S}^{2}\right)\end{array}$ & $\mathrm{F}_{\text {hitung }}$ & $\mathrm{F}_{\text {tabel }}$ & Kesimpulan \\
\hline Eksperimen & 142,12 & 1,096 & 1,882 & Kedua varians \\
Kontrol & 129,70 & 1,096 & 1,882 & populasi homogen \\
\hline
\end{tabular}

Uji Hipotesis Nilai Pretest dan posttest

Pengujian hipotesis nilai pretest dilakukan untuk mengetahui ada atau tidaknya perbedaan pemahaman konsep matematika siswa dengan menggunakan pembelajaran inquiry dan dengan menggunakan pembelajaran ekspositori. Dalam penelitian ini, pengujian hipotesis menggunakan uji-t dengan kriteria yaitu, Ho: $\mu_{1} \leq \mu_{2}$ dan $\mathrm{H}_{1}$ : $\mu_{1}>\mu_{2}$.

Tabel 11. Rekapitulasi Hasil Perhitungan Uji-t Nilai Pretest

\begin{tabular}{cccc}
\hline $\begin{array}{c}\text { Derajat } \\
\text { Kebebasan }\end{array}$ & $\mathrm{t}_{\text {hitung }}$ & $\begin{array}{c}\mathrm{t}_{\text {tabel }} \\
u_{=0,05}\end{array}$ & Kesimpulan \\
\hline 58 & 2,69 & 2,001 & $\mathrm{H}_{\mathrm{o}}$ ditolak \\
\hline
\end{tabular}

Tabel 12. Rekapitulasi Hasil Perhitungan Uji-t Nilai Posttest

\begin{tabular}{cccc}
\hline $\begin{array}{c}\text { Derajat } \\
\text { Kebebasan }\end{array}$ & $\mathrm{t}_{\text {hitung }}$ & $\begin{array}{c}\mathrm{t}_{\text {tabel }} \\
u_{=0,05}\end{array}$ & Kesimpulan \\
\hline 58 & 9,39 & 2,001 & $\mathrm{H}_{\mathrm{o}}$ ditolak \\
\hline
\end{tabular}




\section{Pembahasan}

Berdasarkanhasil penelitian yang didapat bahwa dalam penggunaan metode inquiryyang diterapkan pada proses pembelajaran dalam penelitian di SMP Karya Pakuan Kabupaten Bogor memperoleh nilai rata-rata pretest $(\bar{X})=$ 52,90 dan nilai rata-rata pretest metode ekspositori $(\bar{X})=52,33$. Sedangkan untuk nilai rata-rata postest kelas eksperimen $(\bar{X})=68,73$ dan nilai rata-rata postest kelas kontrol $(\bar{X})=56,70$. Selain itu metode inquiry memberikan dampak positif terhadap pemahaman konsep matematika siswa. Sebagai contoh siswa lebih bersemangat dalam proses pembelajaran matematika, siswa mampu melibatkan pengalamannya,mampu bertindak lebih aktif dalam mengerjakan soal dan bertanya karena terdapat kegiatan diskusi kelompok, dan melatih kreativitas siswa dalam menjawab soal.

Dari hasil pengujian analisis data, uji normalitas nilai pretest pada kelas eksperimen diperoleh $\mathrm{x}^{2}$ hitung $=9,562$ dan $\mathrm{x}_{\text {tabel }}^{2}=11,07$ dengan taraf signifikansi $5 \%$ yang berarti nilai $\mathrm{x}_{\text {hitung }}^{2}<\mathrm{x}_{\text {tabel }}^{2}$ maka hasilnya adalah data kelas eksperimen berditribusi normal. Sedangkan uji normalitas nilai pretest pada kelas kontrol diperoleh $\mathrm{x}_{\text {hitung }}^{2}=3,511$ dan $\mathrm{x}_{\text {tabel }}^{2}=11,07$ dengan taraf signifikansi $5 \%$ yang berarti nilai $\mathrm{x}_{\text {hitung }}^{2}<\mathrm{x}_{\text {tabel }}^{2}$ maka hasilnya adalah data kelas kontrol berditribusi normal. Dapat disimpulkan nilai pretest kedua data tersebut berdistribusi normal.

Dari hasil pengujian analisis data, uji normalitas nilai postest pada kelas eksperimen diperoleh $\mathrm{x}^{2}$ hitung $=9,751$ dan $\mathrm{x}_{\text {tabel }}^{2}=11,07$ dengan taraf signifikansi $5 \%$ yang berarti nilai $\mathrm{x}_{\text {hitung }}^{2}<\mathrm{x}_{\text {tabel }}^{2}$ maka hasilnya adalah data kelas eksperimen berditribusi normal. Sedangkan uji normalitas nilai postest pada kelas kontrol diperoleh $x_{\text {hitung }}^{2}=9,678$ dan $x_{\text {tabel }}^{2}=11,07$ dengan taraf signifikansi 5\% yang berarti nilai $\mathrm{x}_{\text {hitung }}^{2}<\mathrm{x}_{\text {tabel }}^{2}$ maka hasilnya adalah data kelas kontrol berditribusi normal. Dapat disimpulkan nilai postest kedua data tersebut berdistribusi normal.
Sedangkan dari hasil pengujian analisis data, uji homogenitas nilai pretest pada kelas eksperimen dan kelas kontrol diperoleh varians kelas eksperimen $\left(\mathrm{S}_{\mathrm{A}}^{2}\right)=$ 64,96 dan varians kelas kontrol $\left(\mathrm{S}_{\mathrm{B}}^{2}\right)=$ 56,34. Maka diperoleh nilai $F_{\text {hitung }}=1,153$ dan $F_{\text {tabel }}=1,882$ atau $F_{\text {hitung }}<F_{\text {tabel }}$ sehingga dapat disimpulkan bahwa nilai pretest kedua kelas berasal dari populasi yang homogen.

Sedangkan dari hasil pengujian analisis data, uji homogenitas nilai postest pada kelas eksperimen dan kelas kontrol diperoleh varians kelas eksperimen $\left(\mathrm{S}_{\mathrm{A}}^{2}\right)=$ 142,12 dan varians kelas kontrol $\left(\mathrm{S}_{\mathrm{B}}^{2}\right)=$ 129,70. Maka diperoleh nilai $F_{\text {hitung }}=1,096$ dan $F_{\text {tabel }}=1,882$ atau $F_{\text {hitung }}<F_{\text {tabel }}$ sehingga dapat disimpulkan bahwa nilai posttest kedua kelas berasal dari populasi yang homogen.

Dari hasil pengujian hipotesis statistik nilai pretest diperoleh statistik data nilai $t_{\text {hitung }}=2,69$ dan $t_{\text {tabel }}=2,001$ dengan taraf signifikansi $5 \%$ yang berarti nilai $t_{\text {hitung }}>t_{\text {tabel }}$. Hasil tersebut menunjukkan bahwa $\mathrm{H}_{0}$ ditolak dan $\mathrm{H}_{1}$ diterima. Diterimanya $\mathrm{H}_{1}$, hal ini berarti telah membuktikan kebenaran dari hipotesis yang menyatakan bahwa pemberian metode inquiry berpengaruh terhadap pemahaman konsep matematika siswa.

Dari hasil pengujian hipotesis statistik nilai postest diperoleh statistik data nilai $t_{\text {hitung }}=9,39$ dan $\mathrm{t}_{\text {tabel }}=2,001$ dengan taraf signifikansi $5 \%$ yang berarti nilai $t_{\text {hitung }}>t_{\text {tabel }}$. Hasil tersebut menunjukkan bahwa $\mathrm{H}_{0}$ ditolak dan $\mathrm{H}_{1}$ diterima. Diterimanya $\mathrm{H}_{1}$, hal ini berarti telah membuktikan kebenaran dari hipotesis yang menyatakan bahwa pemberian metode inquiry berpengaruh terhadap pemahaman konsep matematika siswa.

Pada penelitian terdahulu, Nurul Afandi (2014) pada penelitiannya yang berjudul "Pengaruh Metode Pembelajaran Discovery dan Inquiry terhadap Pemahaman Konsep Matematika Siswa SMA Negeri 6 Kundur Kabupaten Karimun Provinsi Kepulauan Riau" menyimpulkan bahwa terdapat pengaruh metode pembelajaran Discovery dan Inquiry terhadap pemahaman konsep matematika 
siswa kelas X SMA Negeri 6 Kundur. Hal ini ditunjukkan dari hasil dan perhitungan diperoleh $t_{\text {hitung }}=4,09$, dengan $U=0,05$ dan $\mathrm{dk}=50$ dari daftar distribusi diperoleh $\mathrm{t}_{\text {table }}$ $=2,01$.

Maka dari penelitian terdahulu dan penelitian yang telah dilakukan diperoleh bahwa pemberian metode inquiry terdapat pengaruh yang signifikan terhadap pemahaman konsep matematika siswa pada pokok bahasan bangun ruang sisi lengkung.

\section{Simpulan}

Berdasarkan hasil perhitungan uji hipotesis yang menggunakan uji-t didapat bahwa pemahaman konsep matematika kelas eksperimen yang diajarkan dengan menggunakan metode inquiry lebih tinggi dibandingkan dengan pemahaman konsep matematika kelas kontrol yang diajarkan dengan menggunakan metode ekspositori. Maka dapat disimpulkan bahwa pemberian metode inquiry terdapat pengaruh yang signifikan terhadap pemahaman konsep matematika siswa pada pokok bahasan bangun ruang sisi lengkung.

\section{Daftar Pustaka}

Akbar, S, Winarni, R., \& Andayani.2013. Kajian Sosiologi Sastra dan Nilai Pendidikan dalam Novel Tuan Guru karya Salman Faris.Jurnal Pendidikan Bahasa dan Sastra UNS, Vol. 1, No. 1.54-68.
Bartolomeus, S. 2013.Visi Pendidikan Ki Hajar Dewantara.Yogyakarta: Kanisius.

Leonard. 2015. EduResearch Raise the Standart. Jakarta: UNINDRA Press.

Liberna, H.,\& Wiratomo, Y. 2013. Metode Pembelajaran Matematika. Jakarta: Mitra Abadi.

Sanjaya, W. 2008.Kurikulum dan Pembelajaran. Jakarta: Kencana Prenada Media Grup.

Siregar, E., \&Hartini, N. 2010.Teori Belajar dan Pembelajaran. Bogor: Ghalia Indonesia.

Sugiyono. 2013. Metode Penelitian Kuantitatif, Kualitatif dan $R \& D$. Bandung: Alfabeta.

Suryabrata, S. 2011. Metodologi Penelitian, Jakarta : Raja Grafindo Persada

Suyanti, D, R. 2010. Strategi Pembelajaran Kimia. Yogyakarta: Graha Ilmu.

Sagala, S. 2011. Konsep dan Makna Pembelajaran.Bandung: Alfabeta.

Zulfiani. 2009. Strategi Pembelajaran Sains. Jakarta: Lembaga Penelitian UIN 